\title{
Interaction of nitric oxide and serotonin in aggressive behavior
}

\author{
Silvana Chiavegatto ${ }^{\mathrm{a}}$ and Randy J. Nelson ${ }^{\mathrm{b}, *}$ \\ a Department and Institute of Psychiatry and Laboratory of Genetics and Molecular Cardiology, Heart Institute (InCor), \\ University of Sao Paulo Medical School, Sao Paulo, Brazil \\ ${ }^{\mathrm{b}}$ Departments of Psychology and Neuroscience, Ohio State University, Columbus, OH 43210, USA
}

Received 30 July 2002; accepted 19 February 2003

\begin{abstract}
Nitric oxide (NO) modulates many behavioral and neuroendocrine responses. Genetic or pharmacological inhibition of the synthetic enzyme that produces NO in neurons evokes elevated and sustained aggression in male mice. Recently, the excessive aggressive and impulsive traits of neuronal NO synthase knockout $\left(\mathrm{nNOS}^{-1-}\right)$ mice were shown to be caused by reductions in serotonin (5-HT) turnover and deficient 5- $\mathrm{HT}_{1 \mathrm{~A}}$ and 5-HT $1 \mathrm{~B}$ receptor function in brain regions regulating emotion. The consistently high levels of aggression observed in $\mathrm{nNOS}^{-1-}$ mice could be reversed by 5-HT precursors and by treatment with specific 5-HT $1 \mathrm{~A}$ and 5-HT $1 \mathrm{~B}$ receptor agonists. The expression of the aggressive phenotype of $\mathrm{nNOS}^{-1-}$ knockout mice requires isolated housing prior to testing. The effects of social factors such as housing condition and maternal care can affect 5-HT and aggression, but the interaction among extrinsic factors, 5-HT, NO, and aggression remains unspecified. Taken together, NO appears to play an important role in normal brain 5-HT function and may have significant implications for the treatment of psychiatric disorders characterized by aggressive and impulsive behaviors.
\end{abstract}

(C) 2003 Elsevier Inc. All rights reserved.

Keywords: Aggression; Violence; Gene knockout; Mouse; Animal model; Isolation; Environmental factors

\section{Introduction}

Nitric oxide (NO), first identified as an endogenous regulator of blood vessel tone, also serves as a neurotransmitter in both the central and the peripheral nervous systems (Baranano et al., 2001; Baranano and Snyder, 2001). NO is an endogenous gas that has several biochemical properties of a free radical at body temperature. NO is very labile, with a half-life of $<5 \mathrm{~s}$; consequently, many studies have manipulated NO indirectly by affecting its synthetic enzyme, nitric oxide synthase (NOS), that transforms arginine into $\mathrm{NO}$ and citrulline. Studies that have used this approach have determined that NO mediates many critical physiological and behavioral functions (reviewed by Nelson et al., 1997).

As noted, the first biological function of NO was discovered in the circulatory system. The ability of nitroglycerin and other organic nitrates to alleviate the pain of angina

\footnotetext{
* Corresponding author. Fax: +1-614-451-3116.

E-mail addresses: schiaveg@usp.br (S. Chiavegatto), rnelson@osu.edu (R.J. Nelson).
}

pectoralis was discovered in the 19th century (reviewed in Parker, 1996), although the mechanisms by which nitrates worked were not discovered until 1980 (Furchgott and Zawadzki, 1980). Relaxation of blood vessels in response to acetylcholine requires that the endothelium secretes a substance initially termed endothelial-derived relaxing factor (Furchgott and Zawadzki, 1980), which was ultimately discovered to be NO (Baranano and Snyder, 2001). NO is also the active metabolite of nitroglycerin, as well as other nitrates, and stimulates blood vessel dilation by activating guanylyl cyclase which induces cGMP formation (Toda, 1995). Thus, NO is an important endogenous mediator of blood vessel tone.

A second biological function of NO emerged in the late 1970s from an independent line of research documenting the carcinogenic risk of dietary nitrosamines. The discovery that both humans and non-human animals produce urinary nitrates in greater amounts than consumed and that this production increases during bacterial infections led to the realization that an endogenous source of nitrates existed (Green et al., 1981). Macrophages convert L-arginine to 
L-citrulline and a reactive species that kills tumor cells in vitro, namely NO (Hibbs et al., 1987). Thus, NO plays an important role in immune function.

It was soon discovered that $\mathrm{NO}$ was also released when cerebellar cultures were stimulated with glutamate (Garthwaite et al., 1988). Pharmacological inhibition of the synthetic enzyme NOS blocked the elevation of cGMP levels in brain slices coincident with activation of the $N$-methyl-Daspartate subtype of glutamate receptor (Bredt and Snyder, 1989; Garthwaite et al., 1989). Since then, many studies of NO affecting neural function have been reported (reviewed in Baranano and Snyder, 2001; Wiesinger, 2001). By acting on the neurons and endothelial cells in the circulatory system, NO exerts profound effects on neuroendocrine function and behavior. In this review, we focus on the role of NO on aggression.

Consistent with its three main functions, three distinct isoforms of NOS have been discovered: (a) in neural tissue (nNOS; NOS-1), (b) an inducible form found in macrophages (iNOS; NOS-2), and (c) in the endothelial tissue of blood vessels (eNOS; NOS-3) (Baranano and Snyder, 2001). Suppression of NO formation by either elimination of arginine or use of $\mathrm{N}$-methyl-L-arginine, a potent NOS inhibitor, affects all three isoforms of NOS.

\section{Behavioral studies of nNOS}

nNOS is localized in high densities within emotionregulating brain regions (Nelson et al., 1997). The specific behavioral role of neuronal NO was examined in nNOS gene knockout $\left(\mathrm{nNOS}^{-1-}\right)$ mice created by homologous recombination (Huang et al., 1993). Informal observation of the newly arrived $\mathrm{nNOS}^{-1-}$ mice in our laboratory revealed high levels of aggression among male cage-mates. We now know that the combination of the missing nNOS gene and the isolated housing conditions within the shipping containers facilitated the extreme aggressiveness when the animals were subsequently housed in groups of five. Behavior, as any phenotype, is the result of genotype-environment interactions. Often, the environmental influences are subtle, and careful behavioral analyses are necessary to untangle lawful relationships regarding the contribution of environment and genotype to the behavioral phenotype (Pfaff, 2001). Male nNOS $^{-1-}$ residents engaged in three to four times more aggressive encounters than wild-type (WT) mice when tested in the intruder-resident model of offensive aggression (Nelson et al., 1995). Nearly $90 \%$ of the aggressive encounters were initiated by the $\mathrm{nNOS}^{-/-}$animals. Similar results were obtained in diadic or group encounters in neutral arenas. In all test situations, male $\mathrm{nNOS}^{-1-}$ mice rarely displayed submissive behaviors (Nelson et al., 1995).

Behavioral studies of mice with targeted deletion of specific genes suffer from the criticism that the gene product is not only missing during the testing period, but also miss- ing throughout development when critical ontogenetic processes, including activation of compensatory mechanisms, may be affected (Nelson, 1997). Furthermore, differences in genetic background might also contribute to the observed changes in behavior of knockout mice (Wolfer et al., 2002). To address these criticisms, mice were treated with 7-nitroindazole (7-NI) $(50 \mathrm{mg} / \mathrm{kg}$ ip), which specifically inhibits nNOS formation in vivo (Demas et al., 1997). Isolated mice treated with 7-NI displayed substantially increased aggression in two different tests of aggression compared to control animals (Demas et al., 1997). Drug treatment did not affect nonspecific locomotor activities. NOS activity in brain homogenates was reduced $>90 \%$ and immunocytochemical staining for citrulline, an indirect marker for the NO synthesis, revealed a dramatic reduction in 7-NI-treated animals (Demas et al., 1997). These pharmacological results confirm and extend the behavioral results obtained in $\mathrm{nNOS}^{-1-}$ mice. Importantly, a combination of the traditional pharmacological approach and a targeted gene disruption approach to the study of aggression enhances the strengths and minimizes the weaknesses of each single approach.

Plasma androgen concentrations influence aggression. $\mathrm{nNOS}^{-1-}$ and WT mice do not differ in blood testosterone concentrations either before or after agonistic encounters (Nelson et al., 1995). However, data on castrated $\mathrm{nNOS}^{-1-}$ males suggest that testosterone is necessary, if not sufficient, to promote increased aggression in these mutants (Kriegsfeld et al., 1997). Castrated $\mathrm{nNOS}^{-1-}$ mice displayed low levels of aggression equivalent to the reduced aggression observed among castrated WT males. Androgenreplacement therapy restored the elevated levels of aggression in $\mathrm{nNOS}^{-1-}$ mice.

A complete battery of sensorimotor tests was conducted to make certain that the mutant mice did not suffer from impairments (e.g., blindness, muscular weaknesses) that may have indirectly facilitated aggression (Nelson, 1997). Although there were no obvious motor impairments in $\mathrm{nNOS}^{-1-}$ mice when tested during the light portion of the day, testing during the animals' nocturnal activity period was critical to reveal motor deficits. Because the cerebellum has the highest numbers of nNOS neurons in the brain, it was surprising that presumed cerebellar functions such as balance and coordination were grossly normal in $\mathrm{nNOS}^{-1-}$ mice. When tested during the night (active phase of the rodents), a striking impairment in balance and motor coordination performance was discovered in the $\mathrm{nNOS}^{-/-} \mathrm{mu}-$ tants, but not observed in the WT mice (Kriegsfeld et al., 1999). The temporal interaction between nNOS activity and the serotonin system has not been described.

Importantly, inappropriate aggressiveness was never observed among female $\mathrm{nNOS}^{-1-}$ mice in these test situations; however, when aggressive behavior was examined in female $\mathrm{nNOS}^{-1-}$ mice in the context of maternal aggression, during which WT females are highly aggressive toward an intruder, $\mathrm{nNOS}^{-1-}$ dams were very docile (Gammie and Nelson, 1999). All other components of maternal 
care were normal in $\mathrm{nNOS}^{-1-}$ females. There were no sensorimotor deficits among the mutant mice of either sex to account for the changes in aggressive behavior. Taken together, these results suggest that NO from neurons has important, but opposite, effects in the mediation of aggression in male and female mice. Although there are no sex differences in NOS activity in the cortex, cerebellum, amygdala, or hypothalamus, androgens generally inhibit and estrogens generally increase NOS activity in the brain (Weiner et al., 1994; Singh et al., 2000).

\section{Behavioral studies of eNOS}

Because $\mathrm{nNOS}^{-1-}$ mice display elevated levels of aggressive behavior compared to WT mice, we investigated aggression in eNOS ${ }^{-1-}$ mice (Demas et al., 1999). In theory, NO from the endothelial tissue could contribute to aggressive behavior. Anecdotal observations, however, indicated that these knockout animals were very docile. Male mice were formally tested using two behavioral paradigms. First, animals were tested using the resident-intruder paradigm; $\mathrm{eNOS}^{-1-}$ mice displayed virtually no aggression during these tests. Second, when tested in a neutral arena with a WT stimulus male, eNOS ${ }^{-1-}$ mice displayed many fewer attacks and a greatly increased latency to attack the stimulus male relative to WT mice (Demas et al., 1999). $\mathrm{eNOS}^{-1-}$ mice exhibit approximately a $35 \%$ increase in basal blood pressure relative to WT mice (110 and $81 \mathrm{~mm} \mathrm{Hg}$, respectively) (Huang et al., 1995). Pharmacological normalization of blood pressure did not affect the absence of aggression in eNOS $^{-1-}$ mice (Demas et al., 1999). These data, in combination with the $\mathrm{nNOS}^{-1-}$ data, suggest that the two isoforms of NOS may normally act to increase $\left(\mathrm{eNOS}^{-/}\right)$and decrease $\left(\mathrm{nNOS}^{-1-}\right)$ aggressive behavior in vivo. Thus, male WT mice with normal concentrations of both isoforms of NOS display only moderate levels of aggression. Maternal aggression was not significantly affected in $\mathrm{eNOS}^{-1-}$ dams (Gammie et al., 2000).

\section{Serotonin (5-HT) and male aggression}

Both pharmacological and clinical approaches have identified serotonin as a key neurotransmitter system involved in aggression and impulsivity. High aggression in humans is correlated with low cerebrospinal fluid concentrations of 5-hydroxyindoleacetic acid (5-HIAA) (the 5-HT metabolite) (Brown et al., 1982; Linnoila et al., 1983) and a blunted response of prolactin to a 5-HT agonist (fenfluramine challenge) (Coccaro, 1992); (Manuck et al., 1998). Brain 5-HT turnover is reduced in aggressive laboratory animals (Valzelli and Garattini, 1968; Giacalone et al., 1968). The negative correlation between 5-HT system activity and aggressive behavior is further substantiated by pharmacological manipulation of the brain 5-HT levels. Drugs that inhibit
5-HT synthesis such as parachlorophenylalanine (pCPA), a tryptophan-free diet, and lesions of 5-HT neurons decrease 5-HT levels and elevate aggression in nonhuman animals (Hole et al., 1977; Gibbons et al., 1978, 1979; Valzelli et al., 1981; Chiavegatto et al., 2001). Conversely, reduction in aggression has been obtained by treatment with 5-HT precursors, 5-HT reuptake inhibitors, 5-HT releasing agents, in addition to 5- $\mathrm{HT}_{1 \mathrm{~A}}$ and 5- $\mathrm{HT}_{1 \mathrm{~B}}$ agonists (Gibbons et al., 1978, 1981; Rolinski and Herbut, 1981; Olivier et al., 1995; Chiavegatto et al., 2001; Miczek and de Almeida, 2001; de Almeida et al., 2001).

Gene targeting strategies in mice that either directly or indirectly affect the functional integrity of the 5-HT system have generally strengthened the influence of 5-HT on aggression (reviewed by Nelson and Chiavegatto, 2001; Miczek et al., 2001). Both male and female mice that lack functional expression of the $5-\mathrm{HT}_{1 \mathrm{~B}}$ receptor gene $\left(5-\mathrm{HT}_{1 \mathrm{~B}}^{-/-}\right)$ are more aggressive (Saudou et al., 1994; Bouwknecht et al., 2001), consistent with the anti-aggressive effect of several 5- $\mathrm{HT}_{1 \mathrm{~B}}$ agonists including eltoprazine (Olivier et al., 1990), CP-94,253 (Fish et al., 1999; Chiavegatto et al., 2001), zolmitriptan (de Almeida et al., 2001), and anpirtoline (Rilke et al., 2001; Miczek and de Almeida, 2001; de Almeida and Miczek, 2002). Although agonists at 5- $\mathrm{HT}_{1 \mathrm{~A}}$ receptors also decrease aggression in rodents (Olivier et al., 1995; Miczek et al., 1998), the mutant mice lacking 5-HT $1 \mathrm{~A}$ receptors are more anxious, less reactive, and possibly less aggressive (Zhuang et al., 1999). Studies of behavioral phenotype in mice derived from a tissue-specific knockout strategy, which discriminates between $5-\mathrm{HT}_{1 \mathrm{~A}}$ presynaptic autoreceptor and 5- $\mathrm{HT}_{1 \mathrm{~A}}$ postsynaptic receptor, could clarify this controversy. In a recent elegant study, $5-\mathrm{HT}_{1 \mathrm{~A}}$ receptors were expressed in mice exclusively in forebrain regions, in a temporally controlled manner (Gross et al., 2002). Although this study implicates the $5-\mathrm{HT}_{1 \mathrm{~A}}$ postsynaptic receptor expression during the early postnatal period in anxiety-like behaviors, aggressive behavior remains to be investigated.

An important component of the 5-HT system is the serotonin transporter (5-HTT). The absence of the 5-HTT gene $\left(5-\mathrm{HTT}^{-/-}\right)$in mice perturbs 5-HT neurotransmission demonstrated by increased basal levels of extracellular 5-HT (Mathews et al., 2000; Daws et al., 2001) and several compensatory alterations in 5-HT homeostasis (Bengel et al., 1998; Li et al., 1999; Rioux et al., 1999; Fabre et al., 2000; Gobbi et al., 2001; La Cour et al., 2001). As expected, male 5-HTT ${ }^{-1-}$ mice are less aggressive than WT animals (Holmes et al., 2002). The data for the genetically altered mice are consistent with pharmacological manipulations; rodents display reduced aggression after administration of 5-HTT inhibitors (Kostowski et al., 1984; Lyons et al., 1999; see also review in Fuller, 1996).

Because of the impressive array of receptor subtypes (15 to date) (Kroeze et al., 2002), and their extensive distribution throughout the nervous system, the precise role of 5-HT in the mediation of aggression remains unspecified. No 
pharmacological approach has been identified that selectively affects only one 5-HT receptor subtype and its signaling mechanism. Further progress in understanding the mechanisms underlying aggression may await the use of tissue-specific targeted gene knockout studies, as well as the development of specific 5-HT agonists and antagonists. Because most of the current data have implicated the 5- $\mathrm{HT}_{1}$ family of 5-HT receptors in aggressive behavior (Miczek et al., 2002), additional efforts might be aimed toward a better understanding of the effects of selective manipulation of these receptors in different brain regions as a guide to future research in aggression.

\section{5-HT and female aggression}

As noted, 5-HT modulates male aggression in several species, including humans. The role of 5-HT in female aggression, which is mostly observed in the context of nest defense, is less well-characterized. In common with male offensive aggression, however, systemic injections of the 5-HT precursor, 5-hydroxytryptophan (5-HTP), in mice reduced maternal aggression (Ieni and Thurmond, 1985). Treatment with a 5- $\mathrm{HT}_{1}$ receptor agonist also diminished maternal aggression in mice (Parmigiani et al., 1989; Racine and Flannelly, 1986). Similarly, treatment with a 5-HT reuptake inhibitor, fluvoxamine, or with $5-\mathrm{HT}_{1}$ or $5-\mathrm{HT}_{2}$ receptor agonists (e.g., 8-OH-DPAT, buspirone, ipsapirone, fluprazine, RU24969, eltoprazine, DOI) reduced maternal aggression in rats (Olivier et al., 1985, 1986, 1995; Ferreira et al., 2000). Centrally administered DOI and 8-OH-DPAT also reduce maternal aggression in rats (De Almeida and Lucion, 1994, 1997). Some of the reduced maternal aggression observed after drug treatment may reflect the general malaise and reduction in locomotor behavior observed after treatment with 5-HT receptor agonists (Olivier et al., 1995). Notably, some studies have found controversial results relating the 5-HT system, 5-HT receptors, and brain regions in rodent maternal aggression (Ieni and Thurmond, 1985; De Almeida and Lucion, 1994, 1997; Ferreira et al., 2000).

Long-term (4-8 weeks) treatment with fluoxetine, a 5-HT-specific reuptake inhibitor, reduced aggression by male prairie voles (Microtus ochrogaster), a biparental rodent, but did not affect maternal aggression (Villalba et al., 1997). This suggests a sex-specific dissociation of the effects of serotonin on aggression. In humans, central 5-HT is inversely correlated with aggression in men, but not women (Cleare and Bond, 1997).

Androgens, either acting directly or via estrogenic metabolites, tend to facilitate aggression, whereas 5-HT tends to inhibit aggression in male mammals. Exposure to androgens early in life affects the expression and distribution of 5-HT receptor subtypes (Simon et al., 1998; Sumner and Fink, 1998; Nelson and Chiavegatto, 2001). Both testosterone and estradiol increase the levels of $5-\mathrm{HT}_{2 \mathrm{~A}}$ receptor mRNA and binding site densities in the brains of male rats

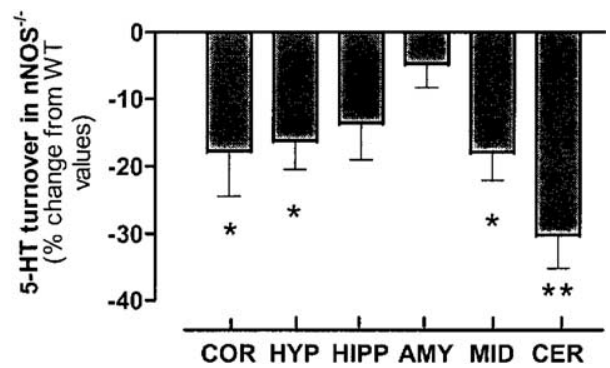

Fig. 1. Mean percentage change ( \pm SEM) of serotonin turnover (5-HIAA/ 5-HT ratio) in the cerebral cortex (COR), hypothalamus (HYP), hippocampus (HIPP), amygdala (AMY), midbrain (MID), and cerebellum (CER) of highly aggressive $\mathrm{nNOS}^{-1-}$ adult male mice compared with WT cohorts. The values of 5-HT turnover measured by HPLC in WT mice are as follows $( \pm \mathrm{SEM}): \mathrm{COR}=0.386 \pm 0.018 ; \mathrm{HYP}=0.569 \pm 0.032 ; \mathrm{HIPP}=$ $0.571 \pm 0.038 ; \mathrm{AMY}=0.470 \pm 0.060 ; \mathrm{MID}=0.586 \pm 0.031 ; \mathrm{CER}=$ $1.094 \pm 0.086(n=5$ or 6$) . * P<0.05, * * P<0.01$ by Student's $t$ test.

(Sumner and Fink, 1998). Importantly, both androgens and estrogens modulate $5-\mathrm{HT}_{1 \mathrm{~A}}$ and $5-\mathrm{HT}_{1 \mathrm{~B}}$ receptor agonist effects on murine aggression (Cologer-Clifford et al., 1999). Indeed, estrogens appear to directly interfere with 5-HT binding (Frankfurt et al., 1994). Thus, sex steroid hormones and 5-HT interact on several levels to influence the likelihood of aggression. Furthermore, estrogens regulate the expression of NOS mRNA in the hypothalamus of rodents (Ceccatelli et al., 1996; Rachman et al., 1998). The interaction among sex steroid hormones, 5-HT, NO, and maternal aggression deserves further study.

\section{5-HT in nNOS knockouts}

Because of the inverse relation of 5-HT system activity and aggression, we hypothesized a disturbed 5-HT neurotransmission in the nNOS null mice as a possible explanation for the excessive aggressiveness of these knockouts. Decreased density and altered distribution of 5-HT terminals were reported in the highly aggressive mice that lack one copy of the brain-derived neurotrophic factor gene $\left(\mathrm{BDNF}^{+/-}\right)$(Lyons et al., 1999), but no alterations in 5-HT immunocytochemistry were detected in either sagittal or coronal slices of the brains of male $\mathrm{nNOS}^{-1-}$ mice (Chiavegatto et al., 2001).

\section{Decrements in serotonin turnover}

Serotonin metabolism, analyzed by the ratio of the metabolite 5-HIAA and the 5-HT levels by HPLC, was significantly reduced in several brain regions including the cortex, hypothalamus, midbrain, and cerebellum of $\mathrm{nNOS}^{-1-}$ in comparison to the WT mice (Chiavegatto et al., 2001) (Fig. 1). Interestingly, these alterations in 5-HT turnover are due to increased levels of 5-HT with no changes in its metabolite in most brain regions studied. The disturbed neurochemical profile appears specific to the 5-HT system, because norepinephrine, dopamine, and metabolites were generally 
unaltered. Taken together, these data make it unlikely that alterations in monoamine oxidase account for the 5-HT abnormalities in the nNOS knockout mice.

\section{Reversal of aggressive phenotype}

The 5-HT precursor 5-HTP was used as a pharmacological tool to increase 5-HT neurotransmission and metabolism in $\mathrm{nNOS}^{-1-}$ and WT mice. In conjunction with an increase in 5-HT levels and turnover in all brain areas investigated, there was a dramatic decrease in the male mice aggressive behavior. Therefore, the aggressive phenotype of the nNOS mutants is a plastic alteration in the 5-HT system and can be completely abolished by a robust increase in the 5-HT metabolism.

\section{Mimicking the aggressive phenotype in WT mice}

The high aggressiveness of nNOS mutants can be induced in the WT mice after a regimen of pCPA injections. Reductions of 5-HT turnover in the brain of WT mice induce aggressiveness comparable to $\mathrm{nNOS}^{-/-}$mice (Chiavegatto et al., 2001).

\section{Deficient $5-H T_{1 A}$ and $5-H T_{1 B}$ receptor function}

Alterations in 5-HT metabolism can reflect or lead to adjustments in 5-HT receptor function. Because both 5- $\mathrm{HT}_{1 \mathrm{~A}}$ and $5-\mathrm{HT}_{1 \mathrm{~B}}$ receptors function as auto- as well as heteroreceptors and are involved in aggressive behavior, they were compared between $\mathrm{nNOS}^{-1-}$ and WT mice. Although the $5 \mathrm{HT}_{1 \mathrm{~A}}$ agonist $8-\mathrm{OH}-\mathrm{DPAT}$ and the $5-\mathrm{HT}_{1 \mathrm{~B}}$ agonist CP-94,253 dose-dependently decreased aggression in both genotypes, significantly higher concentrations of both agonists were required to reduce the aggressive behavior of the nNOS knockouts. The $\mathrm{ED}_{50}$ for the antiaggressive effect of the $5 \mathrm{HT}_{1 \mathrm{~A}}$ agonist in the $\mathrm{nNOS}^{-1-}$ mice is 4-fold higher and for the $5 \mathrm{HT}_{1 \mathrm{~B}}$ agonist 1.8-fold higher than for WT mice. These results suggest hypofunction of the 5- $\mathrm{HT}_{1 \mathrm{~A}}$ and $5-\mathrm{HT}_{1 \mathrm{~B}}$ receptors in the brain of the $\mathrm{nNOS}^{-/-}$mice, thus implicating neuronal-derived NO to the integrity of 5-HT neurotransmission.

\section{5-HT in eNOS knockouts}

The brain monoamines were investigated in the eNOS $^{-1-}$ mice after water-maze training. These mutant mice exhibit an accelerated 5-HT turnover in the frontal cortex and ventral striatum and the 5-HT metabolite is increased in the cerebellum. Dopamine turnover is elevated in the ventral striatum (Frisch et al., 2000). The lack of eNOS gene fails to alter acetylcholine or choline in any of the brain areas examined (Dere et al., 2001). Therefore, the increased activity of the 5-HT system in the $\mathrm{eNOS}^{-/-}$mice is in accordance with the decreased aggression reported in these mutants (Demas et al., 1999), thus strengthening our proposed relationship between NO and 5-HT in aggression. It is interesting to note that the same molecule, $\mathrm{NO}$, whether derived from nNOS or eNOS, has opposite effects on 5-HT, hence leading to opposite effects on aggressive behavior. It seems that differences in the localization of the source of $\mathrm{NO}$ and/or subcellular sites may account for the distinctive disturbances in 5-HT neurotransmission.

\section{5-HT and extrinsic factors that affect aggression}

Several environmental factors, including housing conditions, quality and quantity of social interactions, and parental interactions, can affect both 5-HT and aggressive behavior. The first indications that individual housing conditions could affect behavior were obtained in rats 40 years ago (Hatch et al., 1963). After 4-6 weeks of isolation $100 \%$ of rats displayed clinical symptoms reflecting chronic distress (Hatch et al., 1963). Aggression increases after 3-6 weeks of individual housing (Garattini et al., 1967; Oehler et al., 1985). Coincident with this transient increase in isolationevoked aggression in mice is a decrease of 5-HT metabolism in diverse brain areas (Valzelli and Bernasconi, 1979; Kempf et al., 1984; Rilke et al., 1998, 2001).

Manipulations of 5-HT receptors with various agonists and antagonists have revealed that social isolation in rodents differentially affects 5-HT receptor subtypes (Wright et al., 1991; White et al., 1991; Sanchez et al., 1993; Fone et al., 1996). Binding studies show transient down-regulation of presynaptic $5-\mathrm{HT}_{1 \mathrm{~A}}$ receptors in the midbrain of mice isolated for 3-6 weeks (Rilke et al., 1998). Significant differences in the affinity, but not density, of postsynaptic hippocampal 5- $\mathrm{HT}_{1 \mathrm{~A}}$ receptors between group- or individually housed mice were also noted (Rilke et al., 1998). The effect of social isolation upon other 5-HT receptor subtypes, or other neurotransmitter systems, deserves further investigation.

The aggressive phenotype of $\mathrm{nNOS}^{-1-}$ mice is not expressed if the animals are group-housed from weaning until testing in adulthood. That is, an isolation period is necessary for the hyperaggressive phenotype to become manifest. Currently, we are assessing 5-HT turnover in WT and $\mathrm{nNOS}^{-I-}$ mice that are isolated or group-housed for various periods of time. Maternal influences represent another possible contribution to adult brain 5-HT levels and aggressive behaviors. Maternal separation, the most common model of maternal influences, produces enduring behavioral and neurochemical changes in the limbic system that may affect adult reactivity to stressors (Andersen et al., 1999; Caldji et al., 2000; Matthews et al., 2001; Meaney, 2001).

Acute prolonged or chronic maternal deprivation events produce alterations in molecules related to 5-HT neurotransmission (Vazquez et al., 2000; Matthews et al., 2001; Vazquez et al., 2002). Studies in offspring that have experienced different episodes of maternal separation have 
found up-regulation of 5- $\mathrm{HT}_{1 \mathrm{~A}}$ receptors in the hippocampus (Sibug et al., 2001; Vazquez et al., 2000, 2002), elevated $5-\mathrm{HT}_{1 \mathrm{~B}}$ receptors in the dorsal raphe nucleus (Neumaier et al., 2002) and in the hippocampus (Vazquez et al., 2002), and significant increases in 5- $\mathrm{HT}_{2 \mathrm{~A}}$ mRNA levels in the parietal cortex (Vazquez et al., 2000; Vazquez et al., 2002), but no alteration in the 5- $\mathrm{HT}_{2}$ receptor binding capacities in the cortex (Ogawa et al., 1994).

Alterations in stress-related hormones are also reported (Levine et al., 1991). Twenty-four hour maternal deprivation on postnatal day (PD) 14 elevates basal and stressinduced corticosterone levels, as well as decreases its receptors in the hippocampus of rats (Vazquez et al., 2002). Although glucocorticoid responses are imperfectly developed during the first 2 weeks postnatally, rat pups that were maternally deprived at PD 6, 9, and 12 showed increased basal corticosterone concentrations and elevated stress-induced ACTH and corticosterone concentrations (Vazquez et al., 2000). Thus, dysregulation of the HPA is another potential mechanism through which social factors could affect aggression.

Because maternal separation could merely evoke stress responses to the lack of food or warmth that the missing mother normally provides, pups were deprived of food, warmth, or maternal contact for $24 \mathrm{~h}$ at PD 4, 10, 16, or 22. Serotonin levels, 5-HIAA, and 5-HT turnover were increased in the cortex and caudal brain regions of young pups that were deprived of food, warmth, or maternal contact, but less so in the older preweanlings (Spear and Scalzo, 1985). Thus, both maternal presence and food are necessary early in ontogeny for typical adult 5-HT system functioning, whereas absence of food appeared to be primarily influential in older pups.

A recent study examined the influence of maternal separation during infancy on maternal aggression in adult offspring (Boccia and Pedersen, 2001). A regimen of $3 \mathrm{~h}$ maternal separation of PD 2-14 reduced maternal aggression in rat dams. The agonistic behavior of adult male rats has not been investigated.

Although it remains possible that maternal behavior of genetically altered dams could affect the aggressive phenotypes of knockout offspring, a cross-fostering study comparing wild and domesticated rats showed that aggression of wild rats was higher than that of the laboratory rats regardless of the foster mother (albino or wild) (Lucion et al., 1994).

The increased aggressive behavior of the male nNOS knockout mice as well as their disturbed 5-HT system is unlikely to be due to maternal influences. The maternal behavior of the nNOS ${ }^{-1-}$ dams was not different from that of the WT female mice, and in fact, the $\mathrm{nNOS}^{-1-}$ pups displayed increased average weight compared with WT pups during the testing period (PD 5-10) (Gammie and Nelson, 1999); however, cross-fostering studies are neces- sary to rule out this hypothesis (Meaney, 2001). Also, because maternal behavior is learned by the mother, careful analyses of maternal behavior of knockout mice are required in order to rule out subtle maternal effects (Caldji et al., 2000).

\section{Summary}

Serotonin appears to be the key neurochemical involved in male-typical offensive aggression (Lesch and Merschdorf, 2000; Nelson and Chiavegatto, 2001; Miczek et al., 2001). Targeted gene knockout or pharmacological inhibition of nNOS causes elevated and sustained aggression in male mice, and the $\mathrm{nNOS}^{-1-}$ females show reduced maternal aggression. The excessive aggressive and impulsive traits of male $\mathrm{nNOS}^{-1-}$ mice are caused by reductions in 5 -HT turnover and deficient $5-\mathrm{HT}_{1 \mathrm{~A}}$ and $5-\mathrm{HT}_{1 \mathrm{~B}}$ receptor function in brain regions regulating emotion. The consistently high levels of aggression observed in male $\mathrm{nNOS}^{-1-}$ mice could be reversed by 5 -HT precursors and by treatment with specific $5-\mathrm{HT}_{1 \mathrm{~A}}$ and $5-\mathrm{HT}_{1 \mathrm{~B}}$ receptor agonists. The effects of pharmacological inhibition of nNOS on 5-HT neurotransmission remain to be determined. Similarly, the interactions among NO, 5-HT, and maternal aggression remain unspecified.

Mice lacking the endothelial version of NOS showed enhanced 5-HT turnover in the frontal cortex and ventral striatum and increased 5-HT metabolite in the cerebellum (Frisch et al., 2000). Dopamine turnover was also elevated in the ventral striatum of $\mathrm{eNOS}^{-1-}$ mice. The elevated 5-HT activity in the brains of $\mathrm{eNOS}^{-1-}$ mice corresponds to the reduced aggression shown in these mice compared to WT and $\mathrm{nNOS}^{-1-}$ mice. The differences in the brain distribution of nNOS and eNOS likely contribute to the opposite behavioral effects of NO.

The aggressive phenotype of nNOS ${ }^{-1-}$ knockout mice can be ameliorated by group-housing from weaning. The effects of social factors such as housing condition and maternal care can affect both brain 5-HT levels and aggression, but again the interactions among extrinsic factors, 5-HT, NO, and aggression deserve specific investigation.

Both pharmacological and genetic approaches to the study of aggression have advantages and disadvantages. No pharmacological approach affects only one 5-HT receptor subtype and signaling mechanism. Further progress in understanding the mechanisms underlying aggression may await the use of tissue-specific targeted gene knockout studies, as well as the development of specific 5-HT agonists and antagonists.

Taken together, NO appears to play an important role in normal brain 5-HT function and may have significant implications for the treatment of psychiatric disorders characterized by aggressive and impulsive behaviors. 


\section{Acknowledgments}

Support for the studies reported from our laboratory and for writing this review was provided by NIH Grants $\mathrm{MH}$ 57535 (RJN) and MH57760 (RJN). SC thanks FAPESPBRAZIL (01/01637-5 and 01/09079-1) for financial support.

\section{References}

Andersen, S.L., Lyss, P.J., Dumont, N.L., Teicher, M.H., 1999. Enduring neurochemical effects of early maternal separation on limbic structures. Ann. N. Y. Acad. Sci. 877, 756-759.

Baranano, D.E., Ferris, C.D., Snyder, S.H., 2001. Atypical neural messengers. Trends Neurosci. 24, 99-106.

Baranano, D.E., Snyder, S.H., 2001. Neural roles for heme oxygenase: contrasts to nitric oxide synthase. Proc. Natl. Acad. Sci. USA 98 10996-11002.

Bengel, D., Murphy, D.L., Andrews, A.M., Wichems, C.H., Feltner, D., Heils, A., Mossner, R., Westphal, H., Lesch, K.P., 1998. Altered brain serotonin homeostasis and locomotor insensitivity to 3, 4-methylenedioxymethamphetamine ("Ecstasy") in serotonin transporter-deficient mice. Mol. Pharmacol. 53, 649-655.

Boccia, M.L., Pedersen, C.A., 2001. Brief vs. long maternal separations in infancy: contrasting relationships with adult maternal behavior and lactation levels of aggression and anxiety. Psychoneuroendocrinology 26, 657-672.

Bouwknecht, J.A., Hijzen, T.H., van der Gugten, J., Maes, R.A., Hen, R., Olivier, B., 2001. Absence of 5-HT(1B) receptors is associated with impaired impulse control in male 5-HT(1B) knockout mice. Biol. Psychiatry 49, 557-568.

Bredt, D.S., Snyder, S.H., 1989. Nitric oxide mediates glutamate-linked enhancement of cGMP levels in the cerebellum. Proc. Natl. Acad. Sci. USA 86, 9030-9033.

Brown, G.L., Ebert, M.H., Goyer, P.F., Jimerson, D.C., Klein, W.J., Bunney, W.E., Goodwin, F.K., 1982. Aggression, suicide, and serotonin: relationships to CSF amine metabolites. Am. J. Psychiatry 139, 741746.

Caldji, C., Diorio, J., Meaney, M.J., 2000. Variations in maternal care in infancy regulate the development of stress reactivity. Biol. Psychiatry $48,1164-1174$.

Ceccatelli, S., Grandison, L., Scott, R.E., Pfaff, D.W., Kow, L.M., 1996 Estradiol regulation of nitric oxide synthase mRNA's in rat hypothalamus. Neuroendocrinology 64, 357-363.

Chiavegatto, S., Dawson, V.L., Mamounas, L.A., Koliatsos, V.E., Dawson, T.M., Nelson, R.J., 2001. Brain serotonin dysfunction accounts for aggression in male mice lacking neuronal nitric oxide synthase. Proc. Natl. Acad. Sci. USA 98, 1277-1281.

Cleare, A.J., Bond, A.J., 1997. Does central serotonergic function correlate inversely with aggression? A study using D-fenfluramine in healthy subjects. Psychiatry Res. 69, 89-95.

Coccaro, E.F., 1992. Impulsive aggression and central serotonergic system function in humans: an example of a dimensional brain-behavior relationship. Int. Clin. Psychopharmacol. 7, 3-12.

Cologer-Clifford, A., Simon, N.G., Richter, M.L., Smoluk, S.A., Lu, S., 1999. Androgens and estrogens modulate 5-HT1A and 5-HT1B agonist effects on aggression. Physiol. Behav. 65, 823-828.

Daws, L.C., Montanez, S., Gould, G.G., Owens, W.A., Frazer, A., Murphy, D.L., 2001. Influence of genetic knockout (KO) of the serotonin transporter (5-HTT) on kinetics of 5-HT clearance and 5-HT1B receptor regulation of 5-HT clearance in vivo, Soc. Neurosci. Abstr. pp. 814.18.

De Almeida, R.M., Lucion, A.B., 1994. Effects of intracerebroventricular administration of 5-HT receptor agonists on the maternal aggression of rats. Eur. J. Pharmacol. 264, 445-448.
De Almeida, R.M., Lucion, A.B., 1997. 8-OH-DPAT in the median raphe, dorsal periaqueductal gray and corticomedial amygdala nucleus decreases, but in the medial septal area it can increase maternal aggressive behavior in rats. Psychopharmacology (Berl.) 134, 392-400.

De Almeida, R.M., Miczek, K.A., 2002. Aggression escalated by social instigation or by discontinuation of reinforcement ("frustration") in mice. Inhibition by anpirtoline: A 5-HT(1B) receptor agonist. Neuropsychopharmacology 27, 171-181.

De Almeida, R.M., Nikulina, E.M., Faccidomo, S., Fish, E.W., Miczek, K.A., 2001. Zolmitriptan-a 5-HT1B/D agonist, alcohol, and aggression in mice. Psychopharmacology (Berl.) 157, 131-141.

Demas, G.E., Eliasson, M.J., Dawson, T.M., Dawson, V.L., Kriegsfeld, L.J., Nelson, R.J., Snyder, S.H., 1997. Inhibition of neuronal nitric oxide synthase increases aggressive behavior in mice. Mol. Med. 3, $610-616$.

Demas, G.E., Kriegsfeld, L.J., Blackshaw, S., Huang, P., Gammie, S.C., Nelson, R.J., Snyder, S.H., 1999. Elimination of aggressive behavior in male mice lacking endothelial nitric oxide synthase. J. Neurosci. 19, RC30.

Dere, E., Frisch, C., De Souza Silva, M.A., Godecke, A., Schrader, J., Huston, J.P., 2001. Unaltered radial maze performance and brain acetylcholine of the endothelial nitric oxide synthase knockout mouse. Neuroscience 107, 561-570.

Fabre, V., Beaufour, C., Evrard, A., Rioux, A., Hanoun, N., Lesch, K.P., Murphy, D.L., Lanfumey, L., Hamon, M., Martres, M.P., 2000. Altered expression and functions of serotonin 5-HT1A and 5-HT1B receptors in knock-out mice lacking the 5-HT transporter. Eur. J. Neurosci. 12, $2299-2310$

Ferreira, A., Picazo, O., Uriarte, N., Pereira, M., Fernandez-Guasti, A., 2000. Inhibitory effect of buspirone and diazepam, but not of 8-OHDPAT, on maternal behavior and aggression. Pharmacol. Biochem. Behav. 66, 389-396.

Fish, E.W., Faccidomo, S., Miczek, K.A., 1999. Aggression heightened by alcohol or social instigation in mice: reduction by the 5-HT(1B) receptor agonist CP-94,253. Psychopharmacology (Berl.) 146, 391-399.

Fone, K.C., Shalders, K., Fox, Z.D., Arthur, R., Marsden, C.A., 1996. Increased 5-HT2C receptor responsiveness occurs on rearing rats in social isolation. Psychopharmacology (Berl.) 123, 346-352.

Frankfurt, M., McKittrick, C.R., Mendelson, S.D., McEwen, B.S., 1994. Effect of 5,7-dihydroxytryptamine, ovariectomy and gonadal steroids on serotonin receptor binding in rat brain. Neuroendocrinology 59, 245-250.

Frisch, C., Dere, E., Silva, M.A., Godecke, A., Schrader, J., Huston, J.P., 2000. Superior water maze performance and increase in fear-related behavior in the endothelial nitric oxide synthase-deficient mouse together with monoamine changes in cerebellum and ventral striatum. J. Neurosci. 20, 6694-6700.

Fuller, R.W., 1996. The influence of fluoxetine on aggressive behavior. Neuropsychopharmacology 14, 77-81.

Furchgott, R.F., Zawadzki, J.V., 1980. The obligatory role of endothelial cells in the relaxation of arterial smooth muscle by acetylcholine. Nature 288, 373-376

Garthwaite, J., Charles, S.L., Chess-Williams, R., 1988. Endotheliumderived relaxing factor release on activation of NMDA receptors suggests role as intercellular messenger in the brain. Nature 336, 385-358.

Garthwaite, J., Garthwaite, G., Palmer, R.M., Moncada, S., 1989. NMDA receptor activation induces nitric oxide synthesis from arginine in rat brain slices. Eur. J. Pharmacol. 172, 413-416.

Gammie, S.C., Huang, P.L., Nelson, R.J., 2000. Maternal aggression in endothelial nitric oxide synthase-deficient mice. Horm. Behav. 38, $13-20$.

Gammie, S.C., Nelson, R.J., 1999. Maternal aggression is reduced in neuronal nitric oxide synthase-deficient mice. J. Neurosci. 19, 80278035 .

Garattini, S., Giacalone, E., Valzelli, L., 1967. Isolation, aggressiveness and brain 5-hydroxytryptamine turnover. J. Pharm. Pharmacol. 19, $338-339$. 
Giacalone, E., Tansella, M., Valzelli, L., Garattini, S., 1968. Brain serotonin metabolism in isolated aggressive mice. Biochem. Pharmacol. 17, 1315-1327.

Gibbons, J.L., Barr, G.A., Bridger, W.H., Leibowitz, S.F., 1978. Effects of para-chlorophenylalanine and 5-hydroxytryptophan on mouse killing behavior in killer rats. Pharmacol. Biochem. Behav. 9, 91-98.

Gibbons, J.L., Barr, G.A., Bridger, W.H., Leibowitz, S.F., 1979. Manipulations of dietary tryptophan: effects on mouse killing and brain serotonin in the rat. Brain Res. 169, 139-153.

Gibbons, J.L., Barr, G.A., Bridger, W.H., Leibowitz, S.F., 1981. L-Tryptophan's effects on mouse killing, feeding, drinking, locomotion, and brain serotonin. Pharmacol. Biochem. Behav. 15, 201-216.

Gobbi, G., Murphy, D.L., Lesch, K., Blier, P., 2001. Modifications of the serotonergic system in mice lacking serotonin transporters: an in vivo electrophysiological study. J. Pharmacol. Exp. Ther. 296, 987-995.

Green, L.C., Tannenbaum, S.R., Goldmann, P., 1981. Nitrate synthesis in the germ free and conventional rat. Science 212, 56-58.

Gross, C., Zhuang, X., Stark, K., Ramboz, S., Oosting, R., Kirby, L., Santarelli, L., Beck, S., Hen, R., 2002. Serotonin1A receptor acts during development to establish normal anxiety-like behaviour in the adult. Nature 416, 396-400.

Hatch, A., Wiberg, G., Balazs, T., Grice, H., 1963. Isolation syndrome in rats. Science 142, 507.

Hibbs Jr, J.B., Taintor, R.R., Vavrin, Z., 1987. Macrophage cytotoxicity: role for L-arginine deiminase and imino nitrogen oxidation to nitrite. Science 235, 473-476.

Hole, K., Johnson, G.E., Berge, O.G., 1977. 5,7-Dihydroxytryptamine lesions of the ascending 5-hydroxytryptamine pathways: habituation, motor activity and agonistic behavior. Pharmacol. Biochem. Behav. 7, 205-210.

Holmes, A., Murphy, D.L., Crawley, J.N., 2002. Reduced aggression in mice lacking the serotonin transporter. Psychopharmacology (Berl.) $161,160-167$.

Huang, P.L., Dawson, T.M., Bredt, D.S., Snyder, S.H., Fishman, M.C., 1993. Targeted disruption of the neuronal nitric oxide synthase gene. Cell 75, 1273-1286.

Huang, P.L., Huang, Z., Mashimo, H., Bloch, K.D., Moskowitz, M.A., Bevan, J.A., Fishman, M.C., 1995. Hypertension in mice lacking the gene for endothelial nitric oxide synthase. Nature 377, 239-242.

Ieni, J.R., Thurmond, J.B., 1985. Maternal aggression in mice: effects of treatments with PCPA, 5-HTP and 5-HT receptor antagonists. Eur. J. Pharmacol. 111, 211-220

Kempf, E., Puglisi-Allegra, S., Cabib, S., Schleef, C., Mandel, P., 1984 Serotonin levels and turnover in different brain areas of isolated aggressive or non-aggressive strains of mice. Prog. Neuropsychopharmacol. Biol. Psychiatry 8, 365-371.

Kostowski, W., Valzelli, L., Kozak, W., Bernasconi, S., 1984. Activity of desipramine, fluoxetine and nomifensine on spontaneous and p-CPAinduced muricidal aggression. Pharmacol. Res. Commun. 16, 265-271.

Kriegsfeld, L.J., Dawson, T.M., Dawson, V.L., Nelson, R.J., Snyder, S.H., 1997. Aggressive behavior in male mice lacking the gene for neuronal nitric oxide synthase requires testosterone. Brain Res. 769, 66-70.

Kriegsfeld, L.J., Eliasson, M.J., Demas, G.E., Blackshaw, S., Dawson, T.M., Nelson, R.J., Snyder, S.H., 1999. Nocturnal motor coordination deficits in neuronal nitric oxide synthase knock-out mice. Neuroscience $89,311-315$

Kroeze, W.K., Kristiansen, K., Roth, B.L., 2002. Molecular biology of serotonin receptors structure and function at the molecular level. Curr. Top. Med. Chem. 2, 507-528

La Cour, C.M., Boni, C., Hanoun, N., Lesch, K.P., Hamon, M., Lanfumey, L., 2001. Functional consequences of 5-HT transporter gene disruption on 5-HT(1a) receptor-mediated regulation of dorsal raphe and hippocampal cell activity. J. Neurosci. 21, 2178-2185.

Lesch, K.P., Merschdorf, U., 2000. Impulsivity, aggression, and serotonin: a molecular psychobiological perspective. Behav. Sci. Law 18, 581604.
Levine, S., Huchton, D.M., Wiener, S.G., Rosenfeld, P., 1991. Time course of the effect of maternal deprivation on the hypothalamic-pituitaryadrenal axis in the infant rat. Dev. Psychobiol. 24, 547-558.

Li, Q., Wichems, C., Heils, A., Van De Kar, L.D., Lesch, K.P., Murphy, D.L., 1999. Reduction of 5-hydroxytryptamine (5-HT) (1A)-mediated temperature and neuroendocrine responses and 5-HT(1A) binding sites in 5-HT transporter knockout mice. J. Pharmacol. Exp. Ther. 291, 999-1007.

Linnoila, M., Virkkunen, M., Scheinin, M., Nuutila, A., Rimon, R., Goodwin, F.K., 1983. Low cerebrospinal fluid 5-hydroxyindoleacetic acid concentration differentiates impulsive from nonimpulsive violent behavior. Life Sci. 33, 2609-2614.

Lucion, A.B., De Almeida, R.M., De Marques, A.A., 1994. Influence of the mother on development of aggressive behavior in male rats. Physiol. Behav. 55, 685-689.

Lyons, W.E., Mamounas, L.A., Ricaurte, G.A., Coppola, V., Reid, S.W., Bora, S.H., Wihler, C., Koliatsos, V.E., Tessarollo, L., 1999. Brainderived neurotrophic factor-deficient mice develop aggressiveness and hyperphagia in conjunction with brain serotonergic abnormalities. Proc. Natl. Acad. Sci. USA 96, 15239-15244.

Manuck, S.B., Flory, J.D., McCaffery, J.M., Matthews, K.A., Mann, J.J., Muldoon, M.F., 1998. Aggression, impulsivity, and central nervous system serotonergic responsivity in a nonpatient sample. Neuropsychopharmacology 19, 287-299.

Mathews, T.A., Fedele, D.E., Unger, E.L., Lesch, K-P., Murphy, D.L., Andrews, A.M., 2000. Effects of serotonin transporter inactivation on extracellular 5-HT levels, in vivo microdialysis recovery and MDMAinduced release of serotonin and dopamine in mouse striatum. Soc. Neurosci. Abstr. 624, 3.

Matthews, K., Dalley, J.W., Matthews, C., Tsai, T.H., Robbins, T.W., 2001. Periodic maternal separation of neonatal rats produces regionand gender-specific effects on biogenic amine content in postmortem adult brain. Synapse 40, 1-10.

Meaney, M.J., 2001. Maternal care, gene expression, and the transmission of individual differences in stress reactivity across generations. Ann. Rev. Neurosci. 24, 1161-1192.

Miczek, K.A., De Almeida, R.M., 2001. Oral drug self-administration in the home cage of mice: alcohol-heightened aggression and inhibition by the 5-HT1B agonist anpirtoline. Psychopharmacology (Berl.) 157, 421-429.

Miczek, K.A., Fish, E.W., DeBold, J.F., De Almeida, R.M., 2002. Social and neural determinants of aggressive behavior: pharmacotherapeutic targets at serotonin, dopamine, and gamma-aminobutyric acid systems. Psychopharmacology (Berl.) 163, 434-458.

Miczek, K.A., Hussain, S., Faccidomo, S., 1998. Alcohol-heightened aggression in mice: attenuation by 5-HT1A receptor agonists. Psychopharmacology (Berl.) 139, 160-168.

Miczek, K.A., Maxson, S.C., Fish, E.W., Faccidomo, S., 2001. Aggressive behavioral phenotypes in mice. Behav. Brain Res. 125, 167-181

Nelson, R.J., 1997. The use of genetic "knockout" mice in behavioral endocrinology research. Horm. Behav. 31, 188-196.

Nelson, R.J., Chiavegatto, S., 2001. Molecular basis of aggression. Trends Neurosci. 24, 713-719.

Nelson, R.J., Demas, G.E., Huang, P.L., Fishman, M.C., Dawson, V.L., Dawson, T.M., Snyder, S.H., 1995. Behavioural abnormalities in male mice lacking neuronal nitric oxide synthase. Nature 378, 383-386.

Nelson, R.J., Kriegsfeld, L.J., Dawson, V.L., Dawson, T.M., 1997. Effects of nitric oxide on neuroendocrine function and behavior. Front. Neuroendocrinol. 18, 463-491.

Neumaier, J.F., Edwards, E., Plotsky, P.M., 2002. 5-HT(1B) mrna regulation in two animal models of altered stress reactivity. Biol. Psychiatry 51, 902-908.

Oehler, J., Jahkel, M., Schmidt, J., 1985. The influence of chronic treatment with psychotropic drugs on behavioral changes by social isolation. Pol. J. Pharmacol. Pharm. 37, 841-849.

Ogawa, T., Mikuni, M., Kuroda, Y., Muneoka, K., Mori, K.J., Takahashi, K., 1994. Periodic maternal deprivation alters stress response in adult 
offspring: potentiates the negative feedback regulation of restraint stress-induced adrenocortical response and reduces the frequencies of open field-induced behaviors. Pharmacol. Biochem. Behav. 49, 961967.

Olivier, B., Mos, J., Rasmussen, D., 1990. Behavioural pharmacology of the serenic, eltoprazine. Drug Metab. Drug Interact. 8, 31-83.

Olivier, B., Mos, J., van Oorschot, R., 1985. Maternal aggression in rats: effects of chlordiazepoxide and fluprazine. Psychopharmacology (Berl.) 86, 68-76.

Olivier, B., Mos, J., van Oorschot, R., 1986. Maternal aggression in rats: lack of interaction between chlordiazepoxide and fluprazine. Psychopharmacology (Berl.) 88, 40-43.

Olivier, B., Mos, J., van Oorschot, R., Hen, R., 1995. Serotonin receptors and animal models of aggressive behavior. Pharmacopsychiatry 28 (Suppl. 2), 80-90.

Parker, J.A., 1996. Organic nitrates: new formulations and their clinical advantages. Am. J. Cardiol. 77, 38C-40C.

Parmigiani, S., Rodgers, R.J., Palanza, P., Mainardi, M., Brain, P.F., 1989. The inhibitory effects of fluprazine on parental aggression in female mice are dependent upon intruder sex. Physiol. Behav. 46, 455-459.

Pfaff, D., 2001. Precision in mouse behavior genetics. Proc. Natl. Acad. Sci. USA 98, 5957-5960.

Rachman, I.M., Unnerstall, J.R., Pfaff, D.W., Cohen, R.S., 1998. Regulation of neuronal nitric oxide synthase mRNA in lordosis-relevant neurons of the ventromedial hypothalamus following short-term estrogen treatment. Brain Res. Mol. Brain Res. 59, 105-108.

Racine, M.A., Flannelly, K.J., 1986. The offensive nature of maternal aggression in mice- effects of fluprazine hydrochloride. Aggress. Behav. 12, 417-424.

Rilke, O., Freier, D., Jahkel, M., Oehler, J., 1998. Dynamic alterations of serotonergic metabolism and receptors during social isolation of lowand high-active mice. Pharmacol. Biochem. Behav. 59, 891-896.

Rilke, O., Will, K., Jahkel, M., Oehler, J., 2001. Behavioral and neurochemical effects of anpirtoline and citalopram in isolated and group housed mice. Prog. Neuropsychopharmacol. Biol. Psychiatry 25, 11251144.

Rioux, A., Fabre, V., Lesch, K.P., Moessner, R., Murphy, D.L., Lanfumey, L., Hamon, M., Martres, M.P., 1999. Adaptive changes of serotonin 5-HT2A receptors in mice lacking the serotonin transporter. Neurosci. Lett. 262, 113-116.

Rolinski, Z., Herbut, M., 1981. The role of the serotonergic system in foot shock-induced behavior in mice. Psychopharmacology (Berl.) 73, 246251.

Sanchez, C., Arnt, J., Hyttel, J., Moltzen, E.K., 1993. The role of serotonergic mechanisms in inhibition of isolation-induced aggression in male mice. Psychopharmacology (Berl.) 110, 53-59.

Saudou, F., Amara, D.A., Dierich, A., LeMeur, M., Ramboz, S., Segu, L., Buhot, M.C., Hen, R., 1994. Enhanced aggressive behavior in mice lacking 5-HT1B receptor. Science 265, 1875-1878.

Sibug, R.M., Oitzl, M.S., Workel, J.O., de Kloet, E.R., 2001. Maternal deprivation increases 5-HT(1A) receptor expression in the CA1 and CA3 areas of senescent Brown Norway rats. Brain Res. 912, 95-98.
Simon, N.G., Cologer-Clifford, A., Lu, S.F., McKenna, S.E., Hu, S., 1998. Testosterone and its metabolites modulate 5HT1A and 5HT1B agonist effects on intermale aggression. Neurosci. Biobehav. Rev. 23, 325336.

Singh, R., Pervin, S., Shryne, J., Gorski, R., Chaudhuri, G., 2000. Castration increases and androgens decrease nitric oxide synthase activity in the brain: Physiologic implications. Proc. Natl. Acad. Sci. USA 97, 3672-3677.

Spear, L.P., Scalzo, F.M., 1985. Ontogenetic alterations in the effects of food and/or maternal deprivation on 5-HT, 5-HIAA and 5-HIAA/5-HT ratios. Brain Res. 350, 143-157.

Sumner, B.E., Fink, G., 1998. Testosterone as well as estrogen increases serotonin2A receptor mRNA and binding site densities in the male rat brain. Brain Res. Mol. Brain Res. 59, 205-214.

Toda, N., 1995. Nitric oxide and the regulation of cerebral arterial tone. In: Vincent, S. (Ed.), Nitric Oxide in the Nervous System. Academic Press, New York, pp. 207-226.

Valzelli, L., Bernasconi, S., 1979. Aggressiveness by isolation and brain serotonin turnover changes in different strains of mice. Neuropsychobiology 5, 129-135.

Valzelli, L., Bernasconi, S., Garattini, S., 1981. p-Chlorophenylalanineinduced muricidal aggression in male and female laboratory rats. Neuropsychobiology 7, 315-320.

Valzelli, L., Garattini, S., 1968. Behavioral changes and 5-hydroxytryptamine turnover in animals. Adv. Pharmacol. 6, 249-260.

Vazquez, D.M., Eskandari, R., Zimmer, C.A., Levine, S., Lopez, J.F., 2002. Brain 5-HT receptor system in the stressed infant rat: implications for vulnerability to substance abuse. Psychoneuroendocrinology $27,245-272$.

Vazquez, D.M., Lopez, J.F., Van Hoers, H., Watson, S.J., Levine, S., 2000. Maternal deprivation regulates serotonin $1 \mathrm{~A}$ and $2 \mathrm{~A}$ receptors in the infant rat. Brain Res. 855, 76-82.

Villalba, C., Boyle, P.A., Caliguri, E.J., De Vries, G.J., 1997. Effects of the selective serotonin reuptake inhibitor fluoxetine on social behaviors in male and female prairie voles (Microtus ochrogaster). Horm. Behav. 32, 184-191.

Weiner, C.P., Lizasoain, I., Baylis, S.A., Knowles, R.G., Charles, I.G., Moncada, S., 1994. Induction of calcium-dependent nitric oxide synthases by sex hormones. Proc. Natl. Acad. Sci. USA 91, 5212-5216.

Wiesinger, H., 2001. Argine metabolism and the synthesis of nitric oxide in the nervous system. Prog. Neurobiol. 64, 365-391.

White, S.M., Kucharik, R.F., Moyer, J.A., 1991. Effects of serotonergic agents on isolation-induced aggression. Pharmacol. Biochem. Behav. 39, 729-736.

Wolfer, D.P., Crusio, W.E., Lipp, H.P., 2002. Knockout mice: simple solutions to the problems of genetic background and flanking genes. Trends Neurosci. 25, 336-340.

Wright, I.K., Ismail, H., Upton, N., Marsden, C.A., 1991. Effect of isolation rearing on 5-HT agonist-induced responses in the rat. Psychopharmacology (Berl.) 105, 259-263.

Zhuang, X., Gross, C., Santarelli, L., Compan, V., Trillat, A.C., Hen, R., 1999. Altered emotional states in knockout mice lacking 5-HT1A or 5-HT1B receptors. Neuropsychopharmacology 21, 52S-60S. 